\title{
LIPOLYSIS PROFILE OF SOME NON-EUROPEAN RAW MILK CHEESE VARIETIES: A REVIEW
}

\author{
Aikaterini GEORGALA ${ }^{1}$
}

Received July 20, 2016; accepted November 25, 2016.

Delo je prispelo 20. julija 2016, sprejeto 25. novembra 2016 .

\begin{abstract}
Lipolysis profile of some non-European raw milk cheese varieties: a review

This review focuses on the lipolysis profile of some non-European raw milk cheese varieties. Lipolysis data of some traditional/artisanal non-European raw milk cheeses such as cheeses ripened in an animal skin, cheeses ripened in brine, cheeses produced in small scale by local dairies etc., are collected and presented in this study. The main characteristics of these cheeses and their lipolysis profile in general are discussed. Factors such as the type of cheese, the technology applied for cheese making and the age of cheese are shown to influence the lipolysis profile.

Key words: milk products; non-European raw milk cheeses; lipolysis; lipolysis profile
\end{abstract}

\section{INTRODUCTION}

Cheese is known as an excellent food due to its high nutritional value (high amounts of protein, calcium, phosphorous and vitamins $\mathrm{A}$ and $\mathrm{D}$ ) and its high bioavailability. Humans have made cheese for a long time to concentrate and preserve milk. Cheese is one of the oldest known types of manufactured foods (Nelson, 1984). Almost 900 varieties of cheeses are produced worldwide. Cheeses are classified according to their form, manufacture technique, ripening and chemical composition (Pandey et al., 2003).

Traditional dairy products have always been an important component of different communities diet (Salameh et al., 2016). Traditional cheeses are known to be produced locally or regionally for many years and they have an important role in the rural region food culture

\section{Lipolizni profil nekaterih neevropskih vrst sira iz surovega mleka}

Pregled se osredotoča na profile lipolize nekaterih neevropskih vrst sira iz surovega mleka. Zbrani so podatki o lipolizi nekaterih tradicionalnih neevropskih vrst sira iz surovega mleka, ki jih zorijo v živalskih kožah, v slanici in jih proizvajajo $\mathrm{v}$ majhnem obsegu v lokalnih mlekarnah. Opisane so glavne značilnosti teh sirov in njihov lipolitični profil. Dejavniki, kot so tip sira, tehnologija proizvodnje in starost sira, vplivajo na profil lipolize.

Ključne besede: mlečni izdelki, neevropski siri iz surovega mleka; lipoliza; lipolizni profil

(Weichselbaum et al., 2009). The characterization of traditional cheeses is important for the protection of tradition diversity and contributes with data for further research and quality control. Autochthonous cheeses are known to be of particular interest by consumers who care about the nature, origin and nutritional value of food.

In recent decades, raw-milk cheeses have often been considered as risky foods (West, 2008). Despite their safety concern there is still demand for raw milk cheeses. This is due to their strong and unique flavour. Cheeses made from raw milk tend to develop stronger flavours and ripen quickly than cheeses made from pasteurized milk.

Not many countries currently permit the distribution or import of raw milk cheeses due to the microbiological risk of theses cheeses and yet most commercial

1 Agricultural University of Athens, Department of Food Science and Human Nutrition, Laboratory of Dairy Research, Iera Odos 75, 11855, Athens, Greece, e-mail: georgala@aua.gr 
cheeses are produced from pasteurized milk rather than raw milk, to eliminate pathogens.

Consumers' preference shows an increasing trend for raw milk cheeses due to the more intense and stronger flavour of raw milk cheeses as compared to that of pasteurized milk cheeses and the market continuously expands (Casalta et al., 2009; Masoud et al., 2012). The flavour development in raw milk cheeses is mainly due to their naturally existing microbial community. Lactic acid bacteria, which are the dominant indigenous microorganisms of raw milk cheeses, produce pathogen-inhibiting substances that contribute to the inhibition of foodborne pathogenic bacterial growth (Yoon et al., 2016). Nevertheless, outbreaks of food-borne illnesses have been reported by the consumption of raw milk cheeses (Yoon et al., 2016). Thus, cheese making process of raw milk cheese should be accompanied by appropriate ripening period and continuous microbiological monitoring until cheese consumption. As raw-milk cheeses have often been associated with outbreaks of diseases it is referred that raw milk cheeses must be stored under appropriate conditions for at least nineteen (90) days before their consumption (Kurt, 1996). Suitable ripening conditions and procedures could reduce the microbial risk of cheese. Also, the hygiene of the environment of milk production and cheese making and the post-cheese making phase must be constantly microbiologically tested (Yoon et al., 2016).

Cheese ripening is a complex and dynamic biochemical process that includes proteolysis, lipolysis and glycolysis, which result to the development of flavour and texture characteristics of the cheese variety. Lipolysis plays an important role in the development of cheese flavour. The triglycerides in all cheese varieties undergo hydrolysis (lipolysis) by the action of lipases originating from milk, rennet paste, starter culture bacteria, adjunct starter culture microorganisms, or non-starter bacteria (Fox et al., 2000; Franco et al. 2001), which result in the liberation of free fatty acids (FFAs) during cheese ripening. Free fatty acids may directly contribute to cheese flavour, especially the short and medium chain FFAs, or act as precursors of other flavour components such as aldehydes, ketones, esters etc.

Lipolysis level depends on cheese variety and ranges from slight to very extensive. Extensive lipolysis is observed in surface ripened and some Italian cheese varieties while low lipolysis is found in brined cheese varieties.

As pasteurization of milk inactivates the majority of indigenous milk lipase there are significant differences on cheese lipolysis between the raw and the pasteurized milk cheeses. However, it must be mentioned that lipolytic enzymes are not only originated from raw milk but also they are coming from starter and adjunct cultures, non-starter bacteria, the rennet paste and/or exogenous lipases.

A lot of information is available in the literature concerning the lipolysis level of cheeses made from pasteurized milk at industrial scale. However, there are several traditional cheese varieties that are produced by small-scale cheese makers at local level in different regions of the world. Raw milk cheeses are an important part of the economy and traditions of many European but also non-European countries. Most of these products are made from raw milk using traditional methods and some of them are made with no standard production technique. The objective of this article was to collect and review published literature data on the lipolysis profile of some non-European raw milk cheeses.

\section{LIPOLYSIS IN NON-EUROPEAN RAW MILK CHEESES}

\subsection{TULUM CHEESE}

Cheeses that ripen in a sack of animal skin are produced in Turkey, Lebanon, Croatia, Bosnia and Herzegovina, Montenegro (Yilmaz et al., 2005; Ceylan et al., 2007; Serhan et al., 2010; Kalit et al., 2014). These artisanal cheeses are relatively unexplored, except some Turkish and Lebanese cheese varieties (Yilmaz et al. 2005; Ceylan et al. 2007; Serhan et al. 2010). Cheeses that ripen in an animal skin have an unique, strong and piquant taste as compared to the classically ripened cheeses. This is due to the different biochemical processes that take place in the sack as a result of the anaerobic conditions in the sack and the possible presence of moulds inside the sack. Lipolysis is the main biochemical process that is responsible for the formation of cheese aroma and flavour and led to the formation of free fatty acids during the cheese ripening in an animal skin.

Tulum cheese is one of the most popular Mediterranean cheeses that are ripened in a skin bag (Salameh et al., 2016) and is mainly produced in the East and Central Anatolia regions of Turkey. It is widely popular in Turkey and has a high economic value.

Tulum cheese can be produced from whole, semi skimmed or skimmed ewes', goats', cows' and buffalos' milk or their mixture, has a high fat content, a buttery and pungent flavor, a crumbly, semi-hard texture, a strong flavour and is dispersible in the mouth (Yilmaz et al., 2005).

Tulum cheese is traditionally made from raw ewe's milk without an addition of starter culture. Home-made calf rennet is used for milk coagulation. At the end of the Tulum cheese making process the cheese curd is tight- 
ly filled into a goat-skin bag named "tulum" until this bag is full and is left to ripen for 3-4 months in caves $\left(5-10{ }^{\circ} \mathrm{C} / 75-80 \%\right.$ relative humidity). Alternatively, it is put into a plastic barrel (Hayaloglu et al., 2007, Salameh et al., 2016).

Intensive lipolysis is observed in cheeses ripened in an animal skin-bag, which is found by the high levels of FFAs and their acid degree value (Kalit et al., 2010). Free fatty acids (FFAs) make a significant contribution to the typical flavour of Tulum cheese (a slight rancid and pungent flavour). FFAs also serve as precursors of other aroma compounds.

Yilmaz et al. (2005) studied the effect of the microbial lipase Piccantase A (lipase obtained from Rhizomucor miehei, purchashed from Gist-brocades Inc., Turkey) on the acceleration of Tulum cheese ripening. The shortening of Tulum cheese ripening time, which is at least four months, could be very useful if there is no loss of its flavour characteristics. So, the commercial microbial lipase Piccantase A was added to the milk before the rennet addition at a level of $0.04,0.06$ and $0.11 \mathrm{~g} \mathrm{~L}^{-1}$ of cheese milk while a control cheese was made without any lipase addition. The levels of FFAs in Tulum cheese samples (control sample and samples with added lipase) are shown in Table 1. The total FFAs content and the volatile FFA content of cheeses were affected by the level of the added microbial lipase. The relative amounts of volatile FFAs varied with ripening time and lipase levels added to milk. The amount of volatile free fatty acids significantly $(p<0.05)$ increased during Tulum cheese ripening, especially in the cheeses made from milk with added Piccantase A (Table 1).

In the control Tulum cheese, made without any Piccantase A addition, the volatile FFAs (C2:0-C10:0) were a small part of the total volatile acids. However, Tulum cheeses produced from Piccantase A added milk had a higher content of volatile FFAs (Table 1). The highest content of volatile FFAs was observed in the Tulum cheese made by the addition of eleven (11) g of Piccantase A per $100 \mathrm{~L}$ of milk. Acetic acid (C2:0) and capric acid (C10:0) were the main volatile acids found in Tulum cheese (Table 1). Total FFAs content was singnificantly $(p<0.05)$ increased during cheese ripening and was also affected by the level of added Palatase A (Table 1). Long-chain free fatty acids dominated in Tulum cheese. The predominant FFAs that were found in Tulum cheese were palmitic acid (C16:0) followed by oleic acid (C18:1) and myristic acid (C14:0). The contents of C14:0, C16:0 and C18:1 FFAs in the 90 days old control Tulum cheese made by raw milk without any Palatase A addition were $26.15 \mathrm{mg} / 100 \mathrm{~g}$ cheese, $50.86 \mathrm{mg} / 100 \mathrm{~g}$ cheese and $49.30 \mathrm{mg} / 100 \mathrm{~g}$ cheese, respectively (Table 1 ). Guler and Uraz (2003) reported higher levels of C16:0
(56.08 mg/100 g cheese) and C18:1 (49.99 mg/100 g cheese) in twenty Tulum cheeses taken from Turkish super markets (Table 1).

Concluding, Yilmaz et al. (2005) showed that the use of Piccantase A in Tulum cheese making increased its FFAs content and its typical flavour but has only a slight effect on the pattern of FFAs. The addition of microbial lipase to cheese milk could be recommended for accelerating the development of Tulum cheese flavour over a short ripening period.

Afyon Tulum cheese is a variety of Tulum cheese in the production of which two different salting methods (salting in brine and dry salting) and two different ripening temperatures $\left(18-20^{\circ} \mathrm{C}\right.$ for 7 days and $+4{ }^{\circ} \mathrm{C}$ for 90 days) were applied (Kara, 2012, Kara et al., 2014). The ripening in brine of Afyon Tulum cheese at relatively high temperatures $\left(18^{\circ} \mathrm{C}\right)$ for 7 days and the dry salting help this cheese to obtain its consumption characteristics in a very short time (about 30 days) (Kara, 2012, Kara et al., 2014).

Kara et al. (2014) studied the free fatty acid composition of Afyon Tulum cheese during ripening. Three (A, B , C) groups of Afyon Tulum cheese that were made by traditional cheese producers and a fourth (D) group of Afyon Tulum cheese that was manufactured experimentally in the Department of Food Hygiene and Technology were examined for their free fatty acid content during 90 days of ripening (Table 1). Generally, for all cheese groups $(A, B, C, D)$ the volatile fatty acids (C4:0C10:0) were increased $(p<0.05)$ up to the 30 days of ripening and decreased thereafter up to the 90 days of cheese ripening. The level of free fatty acids $\mathrm{C} 12: 0-\mathrm{C} 18: 2$ decreased $(p<0.05)$ on the $30^{\text {rd }}$ day of ripening. Then it was increased $(p<0.05)$ again up to the end of ripening (Table 1).

Hayaloglu and Karabulut (2013) examined the free fatty acids profile of eleven different cheese varieties that are sold in Turkey. Cheese samples were collected from different Turkish regions in 2009 year. Divle Tulum cheese was one of the cheese varieties examined by these authors. The production method for Divle Tulum resembles to that for normal Tulum cheese making but with some differences. Divle Tulum is ripened in a natural cave $\left(4-5{ }^{\circ} \mathrm{C}\right.$ and $80 \% \pm 5$ relative humidity) for a long period (Hayaloglu and Karabulut, 2013). Eight (8) samples of Divle Tulum cheese were examined for their free fatty acid content and their mean value is shown in Table 1. Palmitic acid (C16:0) and oleic acid (C18:1) were the main free fatty acids of Divle Tulum cheese samples (Table 1). 


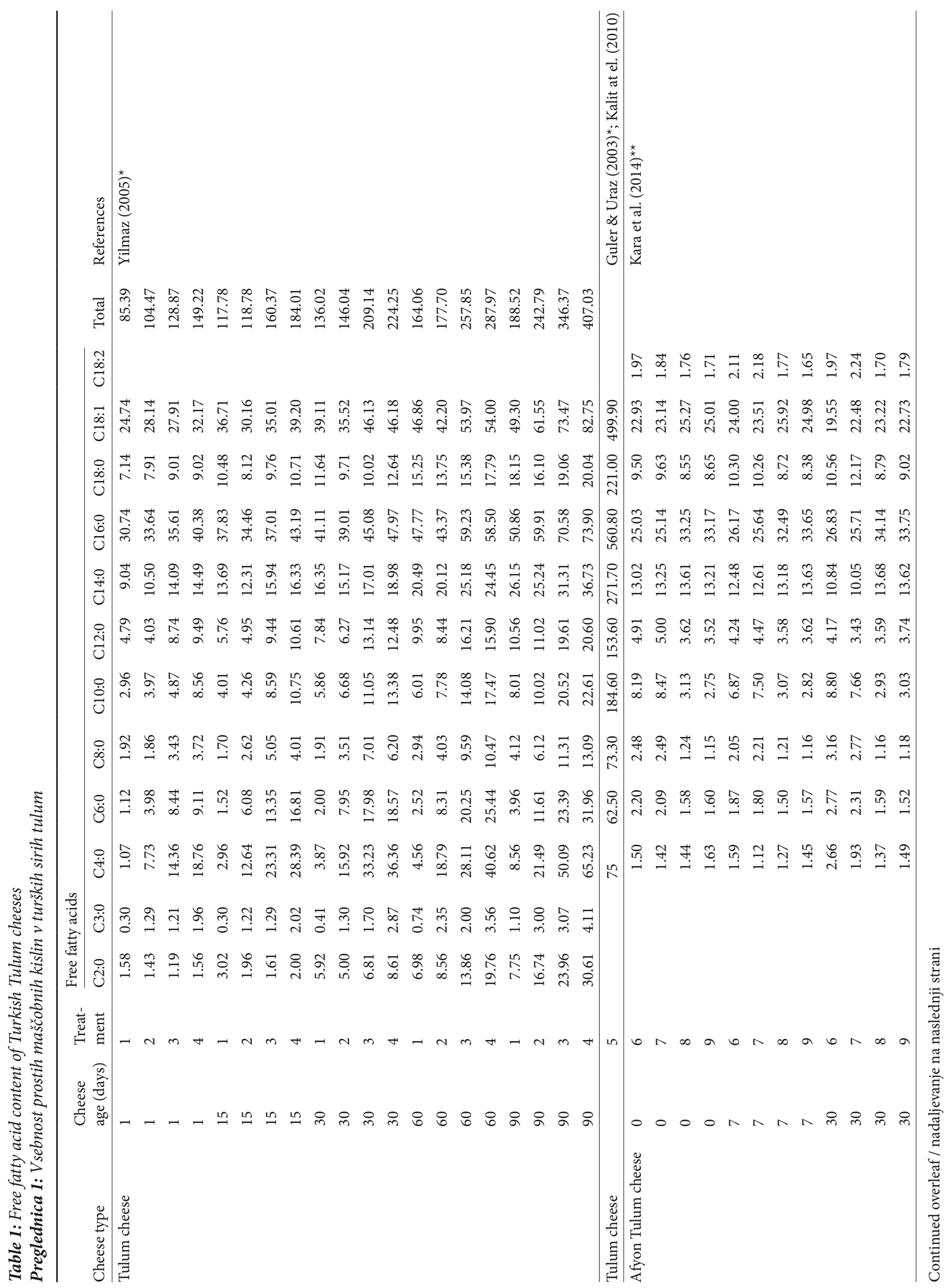




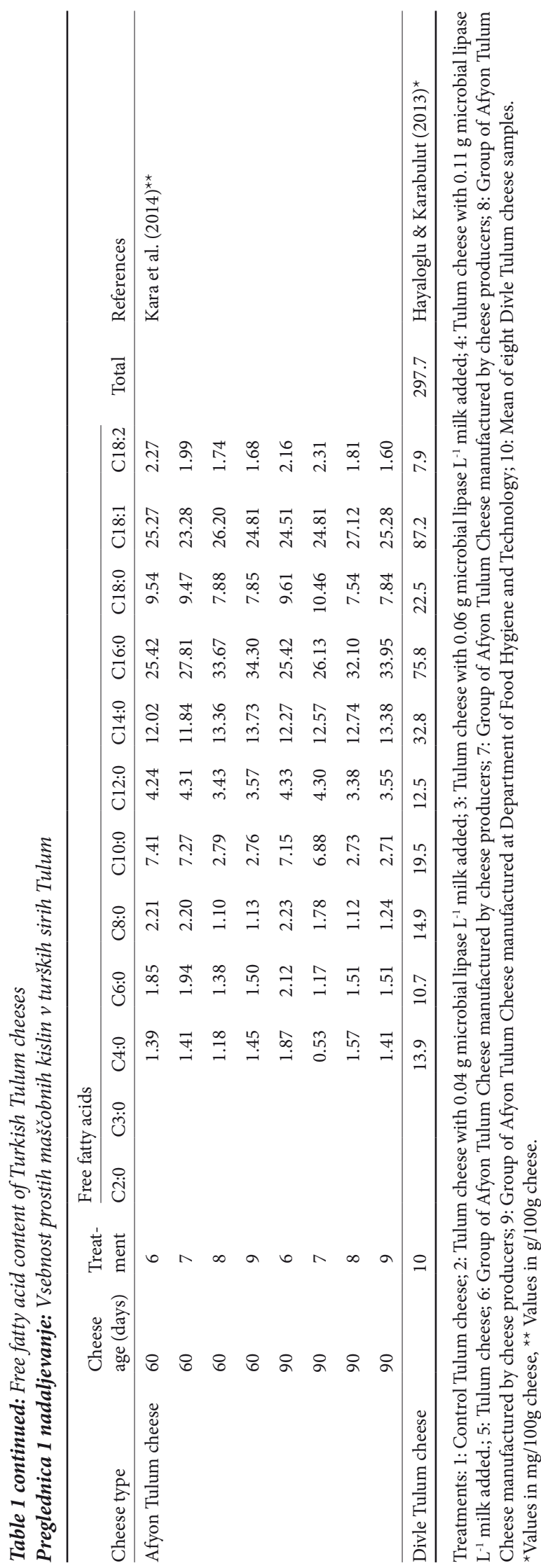

\subsection{SEPET CHEESE}

Sepet cheese is a traditional cheese that is specific to the Aegean region of Turkey. It is named Sepet (basket) cheese as its surface has a basket-weave impression. Baskets made from stalks that were collected near river and moist areas, are used in the production of this cheese (Kamber, 2008). Raw goat's milk is the milk mostly used for its production (Kinik et al., 1999). According to Ercan et al. (2011) for Sepet cheese production raw milk is heated to $40{ }^{\circ} \mathrm{C}$, rennet $(1 \mathrm{~g} / 5 \mathrm{~L}$ of milk) is added and coagulation takes place within 2 hours. It follows cutting of the curd into particles of $1 \mathrm{~cm}^{2}$, draining, placing into baskets, draining and dry salting, ripening in brine $140 \mathrm{~g}$ of $\mathrm{NaCl} / \mathrm{L}$ and finally marketing.

Erkan et al. (2011) examined the volatile profile of traditional Sepet cheeses. Fifty two (52) samples of Sepet cheeses three months old were collected between the years 2008 and 2009 from different Turkish towns that are located near Izmir. FFAs were the most abundant volatile compounds found in all Sepet cheeses. Hexanoic, octanoic, decanoic and butyric acids were found in the highest percentages in the volatile fraction of Sepet cheese in a decreasing order. Similarities on the FFA content of Sepet cheese with that of Minas' cheese, goat's milk Jack cheese and blue cheeses were found (Chiofalo et al., 2004; Frank et al., 2004; Nogueira et al., 2005; Attaie, 2009). The lipolysis index (acid degree value) varied considerably among the examined Sepet cheeses. Its value ranged from $1.64 \mathrm{meq} \mathrm{KOH} / 100 \mathrm{~g}$ fat (minimum value) to $41.63 \mathrm{meq} \mathrm{KOH} / 100 \mathrm{~g}$ fat (maximum value) with an average value (mean) of $6.36 \mathrm{meq} \mathrm{KOH} / 100 \mathrm{~g}$ fat. The variation in lipolysis index of Sepet cheese samples could be attributed to variations in microbial loads, milk species, ripening conditions and season The mean acid degree value ( $6.36 \mathrm{meq} \mathrm{KOH} / 100 \mathrm{~g}$ fat) found in the study of Erkan et al. (2011) was higher than the acid degree value $(3.493 \mathrm{meq} \mathrm{KOH} / 100 \mathrm{~g}$ fat) reported by Kinik et al. (1999).

\subsection{POOSTI CHEESE}

Poosti cheese is a traditional Iranian cheese that is made from raw ewe's milk in the nomadic tribes of Sangesar region which is located in the Semnan province (east of Iran). Ewe's skin is used for cheese preserving during ripening. Poosti cheese production includes coagulation, whey removal (two times), salting, stuffing in the prepared skin and ripening for three months. According to the Hemmatian et al. (2015) Poosti cheese was made as follows: Raw ewe's milk that was taken from a local native sheep heards of the Sermman province was 
clarified by passing it through a thin cloth issue. For milk coagulation lamb rennet was added to the milk at room temperature and left without stirring for about 2 hours. For the removal of whey the cheese curd was put into a rectangular cotton bag. Young cheese was loaded with heavy rocks and pressed for ten days. At this period, salt $(25 \%)$ was added. Also, every day the cheese was under the inside out process. Then, the sheep skin was filled with the prepared cheese and packed tightly. Afterwards, it was kept in a man-made cave for three months at $4-6^{\circ} \mathrm{C}$. The same authors examined the free fatty acid profile of Poosti cheese during 90 days ripening. An increasing trend of the levels of short chain fatty acids (C4:0-C10:0) was found between the day one (1) cheese (beginning of ripening time) and the nineteen (90) day cheese (end of ripening time). The increase of short chain free fatty acids (C4:0-C10:0) content during cheese ripening could be considered as a result of the lipolytic activity of the lipoprotein lipase found in raw milk and the lipases released from the microbial population of raw milk and sheep skin. The amount of medium chain (C12:0-C16:0) free fatty acids content was found to be constant during Poosti cheese ripening. This could be attributed to the inhibitory effects of salt and $\mathrm{pH}$ on the microbial population and their lipolytic activities. On the other hand, the long chain free fatty acids decreased during ripening.

\subsection{LIGHVAN CHEESE}

Several traditional cheeses are produced in different regions of Iran. Lighvan cheese is one of the most popular Iranian traditional cheeses. Due to its pleasant organoleptic properties, Lighvan cheese is popular and widely consumed all over the Iran (Mirzaei et al., 2008). Lighvan cheese is made at Lighvan village in the northwest of Iran. It is a semi-hard, white cheese ripened in brine that is made from raw ovine milk or appropriate mixtures of ovine and caprine milk in which the proportion of the latter is not higher than $20-30 \%$. No starter cultures are added. Since no starter cultures are added the native micro flora plays an important role to the cheese ripening (Tavaria et al., 2006). Lighvan cheese has a mild acidic salty taste and a pleasant flavour and smell. Its unique flavour is appreciated by the consumers. The method used in Lighvan cheese production is artisanal and traditional and all phases of cheese manufacture are manual.

In Lighvan cheese making raw milk is heated to approximately $32{ }^{\circ} \mathrm{C}$ and rennet is added. After the formation of the coagulum the curd is cut into small pieces and collected into a cotton cloth. Aftewards, it was pressed to

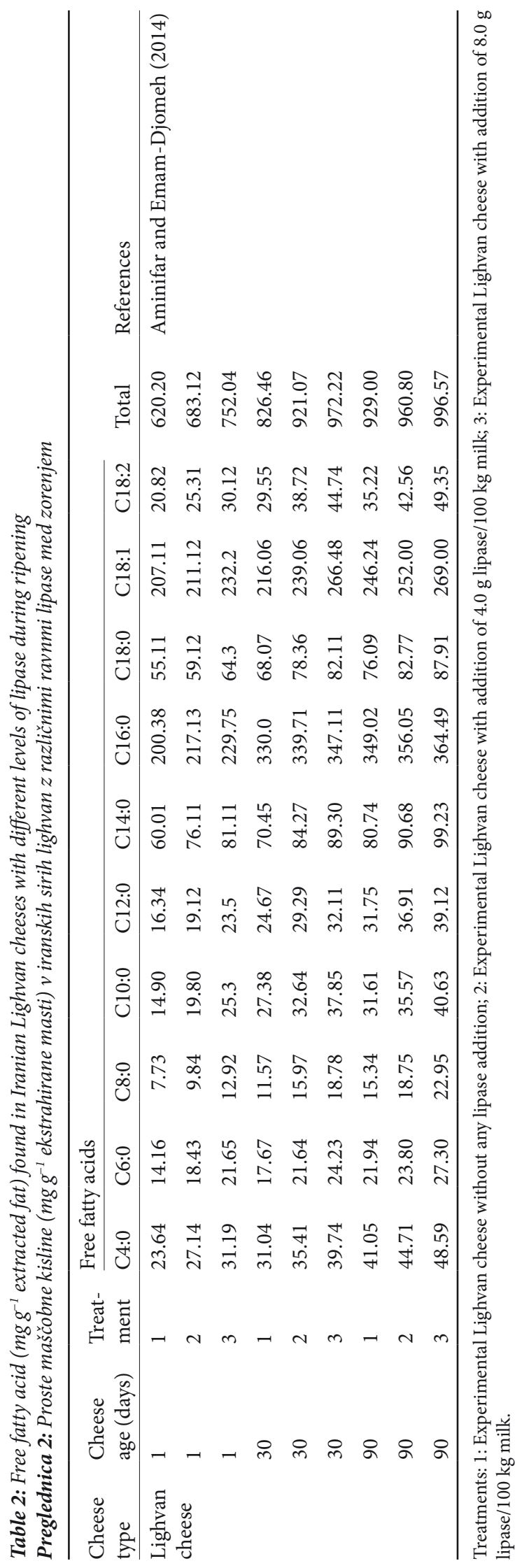


remove whey from the curd, as much as possible. Then the curd was cut into slices and dry-salted on its surface with coarse-grained salt. Finally, the product is put into tins, covered with brined and ripened in natural cells for 2-8 months where the stable temperature and humidity contribute to the formation of the optimal ripening conditions (Mirzaei, 2011).

As Lighvan cheese is made from raw milk, lipolysis plays an important role on its flavour formation (Aminifar and Emam-Djomeh, 2014). Indigenous lipase is known to be the main lipolytic factor in raw milk cheese (Turkoglu, 2011). According to Kafili et al. (2009) the lipolytic activity of yeasts and enterococci found in traditional Lighvan cheese and the milk lipase could play an important role to lipolysis of Lighvan cheese.

The shortening of Lighvan cheese ripening time that is at least three to four months without any defect on cheese properties could be very useful. The acceleration of lipolysis could play an important role in shortening Lighvan's cheese ripening. So, Aminifar and Emam-Djomeh (2014) studied the effect of the addition of different levels of the microbial lipase palatase (lipase obtained from Rhizomucor miehei with an activity of $\geq 20,000 \mathrm{Ug}^{-1}$, purchashed from Sigma-Aldrich, Denmark) on the free fatty acids of Lighvan cheese during ripening. Generally, at different levels $(0,4 \mathrm{~g}$ or $8 \mathrm{~g}$ palatase per $100 \mathrm{~g}$ milk) of added palatase the short chain fatty acids increased significantly (Table 2). Palatase containing cheeses had higher amounts of short chain fatty acids as compared to the control cheese made without any palatase addition. Also, the palatase concentration had a significant effect on the entire free fatty acid content of cheese (Table 2). It is known that medium and long chain fatty acids have no important role in the final cheese aroma. However, their amount at the end of Lighvan cheese ripening was important. Palmitic acid (C16:0) was the most abundant followed by oleic acid (C18:1) and myristic acid (C14:0) (Table 2).

The acid degree value (ADV) method has been used for many years as an index of lipolysis in dairy products. In the ADV method fat is released by the combined ac- tion of detergent, ion exchange and heat. Aliquots of fat are weighted and dissolved in solvent and the free fatty acids are titrated with alcoholic $\mathrm{KOH}(0.02 \mathrm{M})$ using methanolic phenolophhthalein as indicator. Although, the ADV method is tedious, it is reliable for foods containing more than $2 \%$ fat (Fox et al., 2000). Lavasani et al. (2012) studied the lipolysis level over 90 days ripening in brine of Lighvan cheese. The ADV of the Lighvan cheese was between $1.47 \mathrm{mg} \mathrm{KOH} / 100 \mathrm{~g}$ fat and $1.68 \mathrm{mg}$ $\mathrm{KOH} / 100 \mathrm{~g}$ fat at the fifth (5) day and at the nineteen (90) day of ripening, respectively (Table 3 ). The ADV increased during ripening especially after the sixteenth (60) day. The results of this study showed that the native milk lipase was mainly responsible for lipid hydrolysis in Lighvan cheese.

\subsection{URFA CHEESE}

Urfa cheese is an artisanal brined type cheese that is made mainly to the South-eastern Anatolia region of Turkey. Urfa cheese is manufactured from raw milk of the Awassi sheep breed or a mixture of caprine and ovine milks at appropriate ratios. In the traditional way of making Urfa cheese, the milk is not pasteurized and no starter cultures are added. The coagulation of milk is done with the addition of animal rennet. At the end of Urfa cheese making process the cheese blocks are dry salted and stored in $15 \% \mathrm{w} / \mathrm{v}$ pasteurized brine (Ozer et al., 2002). In some regions, before dry-salting, cheese blocks are kept in boiling whey for about $5 \mathrm{~min}$ to give the cheese a more elastic texture.

Kirmaci (2016) study the effect of some wild strains of lactic acid bacteria that were used as starters on the free fatty acid profile of Urfa cheese during ripening. Three different combinations of lactic acid bacteria were used as starters in Urfa cheese made from pasteurized milk. The combinations of the strains used as starters in the cheese making of Urfa cheese were the following: Cheese A: E. faecium ATCC $19434+$ L. lactis subsp. lactis 1B4+ L. garvieae IMAU 50157 (with ratio of $1: 1: 0.5$ ), Cheese

Table 3: Lipolysis expressed as acid degree value (ADV) of some non-European raw milk cheese varieties

Preglednica 3: Lipoliza, izražena v stopinjah kislosti, pri nekaterih neevropskih vrstah sirov iz surovega mleka

\begin{tabular}{lllllllllll}
\hline & \multicolumn{7}{l}{ Ripening time (days) } & & & \\
Cheese type & 1 & 5 & 7 & 15 & 25 & 30 & 45 & 60 & 90 & References \\
\hline Lighvan cheese & & 1.47 & & & 1.51 & & 1.57 & 1.62 & 1.68 & Lavasani et al. (2012) \\
Corrientes Artisanal cheese & 1.03 & 1.32 & 1.63 & 1.96 & & 3.76 & & & & Vasek et al. (2013) \\
Orgu cheese RMC & 0.59 & & & 1.36 & & 1.66 & & 1.88 & 1.97 & Celik and Turkoglu (2007) \\
Orgu cheese PMC & 0.53 & & & 1.14 & & 1.38 & & 1.59 & 1.71 & Celik and Turkoglu (2007) \\
\hline
\end{tabular}

RMC: raw milk cheese, PMC: pasteurized milk cheese 
B: E. durans IMAU60200 + E. faecium ATCC $19434+$ L. lactis subsp. lactis $1 \mathrm{~B} 4$ (with ratio $1: 1: 1$ ) and Cheese C: E. faecium ATCC $19434+$ E. durans IMAU60200+ L. garvieae IMAU $50157+$ L. lactis susp. lactis $1 \mathrm{~B} 4+E$. faecalis KLDSO.0341 (with ratio $1: 1: 1: 1: 1$ ). Also, a control cheese (cheese D) was produced from raw ewe's milk without the addition of any starter culture.

The results of this study showed that the total amount of short chain free fatty acids (C4:0-C8:0) in all cheese samples significantly $(p<0.05)$ increased during the cheese ripening (Table 4 ). The addition of wild bacterial strains to the pasteurized milk significantly $(p<0.005)$ affected the volatile free fatty acid content during cheese ripening (Table 4). Generally, the total FFAs content was significantly higher in cheese $C$ in comparison with the rest cheeses (cheeses $\mathrm{A}, \mathrm{B}$ and $\mathrm{D}$ ) (Table 4). This may be due to the higher lipolytic activity of enterococcal strains found in the cheese $\mathrm{C}$. Although the lipolytic properties of the strains applied in the present case were superior to that of raw milk microflora, the safety of enterococcal strains for cheese applications has to be assured and a number of parameters must be properly addressed before offering a starter or starter combination to cheese industry (Kirmaci, 2016). Total FFAs content of Urfa cheese was significantly lower than that of many other cheese varieties (Kirmaci, 2016). The low lipolysis of Urfa cheese is mainly due to its storing in high salt brine (higher than $12 \%, \mathrm{w} / \mathrm{v}$ ). Other researchers (Katsiari et al., 2000, Pavia et al., 2000) have marked the inhibitory effect of $\mathrm{NaCl}$ on cheese's FFAs content.

Atasoy and Turkoglu (2009) studied the lipolysis in Urfa cheese made from raw and pasteurized goats' and cows' milk with mesophilic or thermophilic starter cultures. In case of Urfa cheese made from pasteurized milk, milk was pasteurized at $65^{\circ} \mathrm{C}$ for 20 minutes, cooled to $32{ }^{\circ} \mathrm{C}$ and $\mathrm{CaCl}_{2}$ was added as well as starter cultures (mesophilic or thermophilic lactic culture at a rate of $1.0 \%$ and $0.5 \% \mathrm{w} / \mathrm{v}$, respectively).

Urfa cheese made from raw milk had higher total free fatty acids levels than the cheese made from pasteurized milk. The FFA content of cheeses made from mesophilic and thermophilic cultures as starters were similar (Table 4). The higher level of lipolysis in raw milk Urfa cheese is mainly due to the indigenous milk lipase and/or the natural microflora that is found in raw milk cheeses. It is well known that the milk lipoprotein lipase which is a relatively heat-labile enzyme can be completely inactivated by heat treatment at $78^{\circ} \mathrm{C}$ for $10 \mathrm{sec}$ (Driessen, 1989). In all of the examined Urfa cheese samples a significant increase of total FFA content during ripening was found (Table 4).

Atasoy and Turkoglu (2008) study the effect of milk heat-treatment at $65^{\circ} \mathrm{C}$ for 20 minutes or at $72{ }^{\circ} \mathrm{C}$ for 5 minutes and the effect of the addition of starter cultures (mesophilic or thermophilic), prior to cheese-making, on the free fatty acid contents of Urfa cheeses during ripening. Raw ovine milk was taken from a local Turkish dairy and was used in the cheese-making process of Urfa cheeses. Five Urfa cheese-making trials were done: $\mathrm{O}_{0}$ (raw milk cheese), $\mathrm{O}_{1}$ (cheese made by milk heattreated at $65{ }^{\circ} \mathrm{C}$ for $20 \mathrm{~min}$ and addition of Lactococcus lactis subsp. lactis and Lactococcus lactis subsp. cremoris as starter cultures), $\mathrm{O}_{2}$ (cheese made by milk heat-treated at $65{ }^{\circ} \mathrm{C}$ for $20 \mathrm{~min}$ and addition of Lactobacillus delbrueckii subsp. bulgaricus and Streptococcus thermophilus as starter cultures), $\mathrm{O}_{3}$ (cheese made by milk heat treated at $72{ }^{\circ} \mathrm{C}$ for $5 \mathrm{~min}$ and addition of Lactococcus lactis subsp. lactis and Lactococcus lactis subsp. cremoris as starter cultures), $\mathrm{O}_{4}$ (cheese made by milk heat treated at $72{ }^{\circ} \mathrm{C}$ for $5 \mathrm{~min}$ and addition of Lactobacillus delbrueckii subsp. bulgaricus and Streptococcus thermophilus as starter cultures). The free fatty acid content of Urfa cheeses were examined at day one (1), day fifteen (15), day thirteen (30), day sixteen (60) and day nineteen (90) of cheese ripening (Table 4). The volatile FFAs content of all experimental cheeses increased during ripening (Table 4). Raw milk cheese showed the highest contents of volatile FFAs (Table 4). Butyric acid and capric acid were the main volatile FFAs found in this study (Table 4). At the end of ripening time the volatile free fatty acids (C4:0 to C10:0) content of raw milk cheese was significantly higher $(p<0.05)$ than that found in cheeses made from heat treated milk $\left(65^{\circ} \mathrm{C}\right.$ for $20 \mathrm{~min}$ or $72{ }^{\circ} \mathrm{C}$ for $5 \mathrm{~min}$ ) (Table 4 ). Also, the addition of starter cultures (mesophilic or thermophilic) to the heat-treated milk significantly $(p<0.001)$ affected the content of volatile FFAs at the end of storage time (Table 4).

Concerning C12:0 to C18:2 free fatty acids there was not found any statistical significant difference between the raw milk cheeses and the heat-treated ones except for oleic acid (C18:1) and linoleic acid (C18:2). Palmitic acid (C16:0) and oleic acid (C18:1) were the most abundant FFAs found in all cheeses (Table 4). However, at the end of ripening time (90 days-old cheeses) the heat-treatments applied to milk statistically affected the FFA content of Urfa cheeses.

Also, at the end of storage time the total FFA contents of mesophilic culture added cheeses were similar to that of thermophilic culture added cheeses but lower than the control cheese made from raw milk (Table 4). The total free fatty acid content of the control raw milk cheese was significantly higher than that of the heattreated milk cheeses (Table 4).

The results of this study showed that the heat treatment of milk at high temperature $\left(72{ }^{\circ} \mathrm{C}\right)$ adversely affected cheese lipolysis while less pronounced were the 


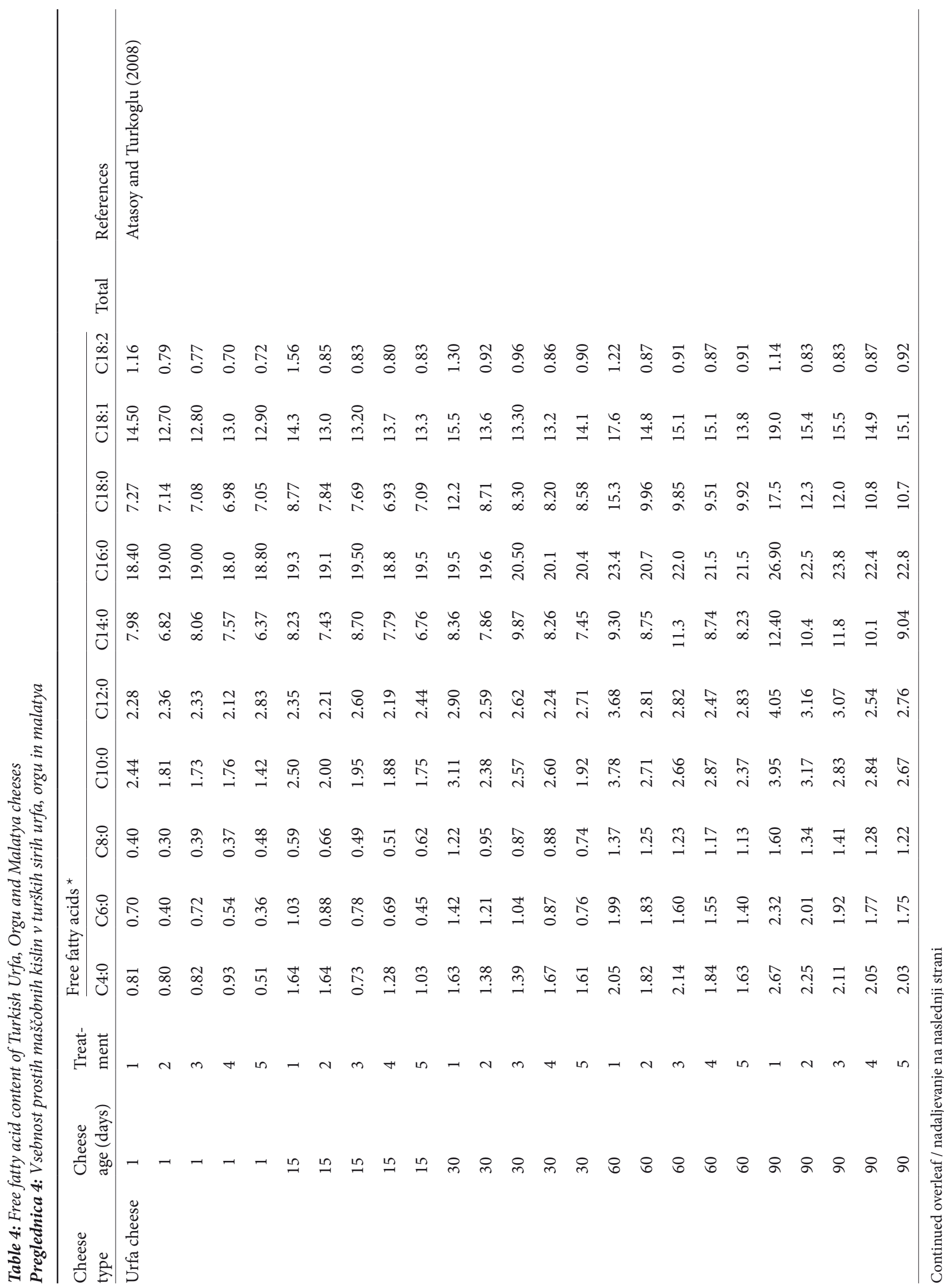




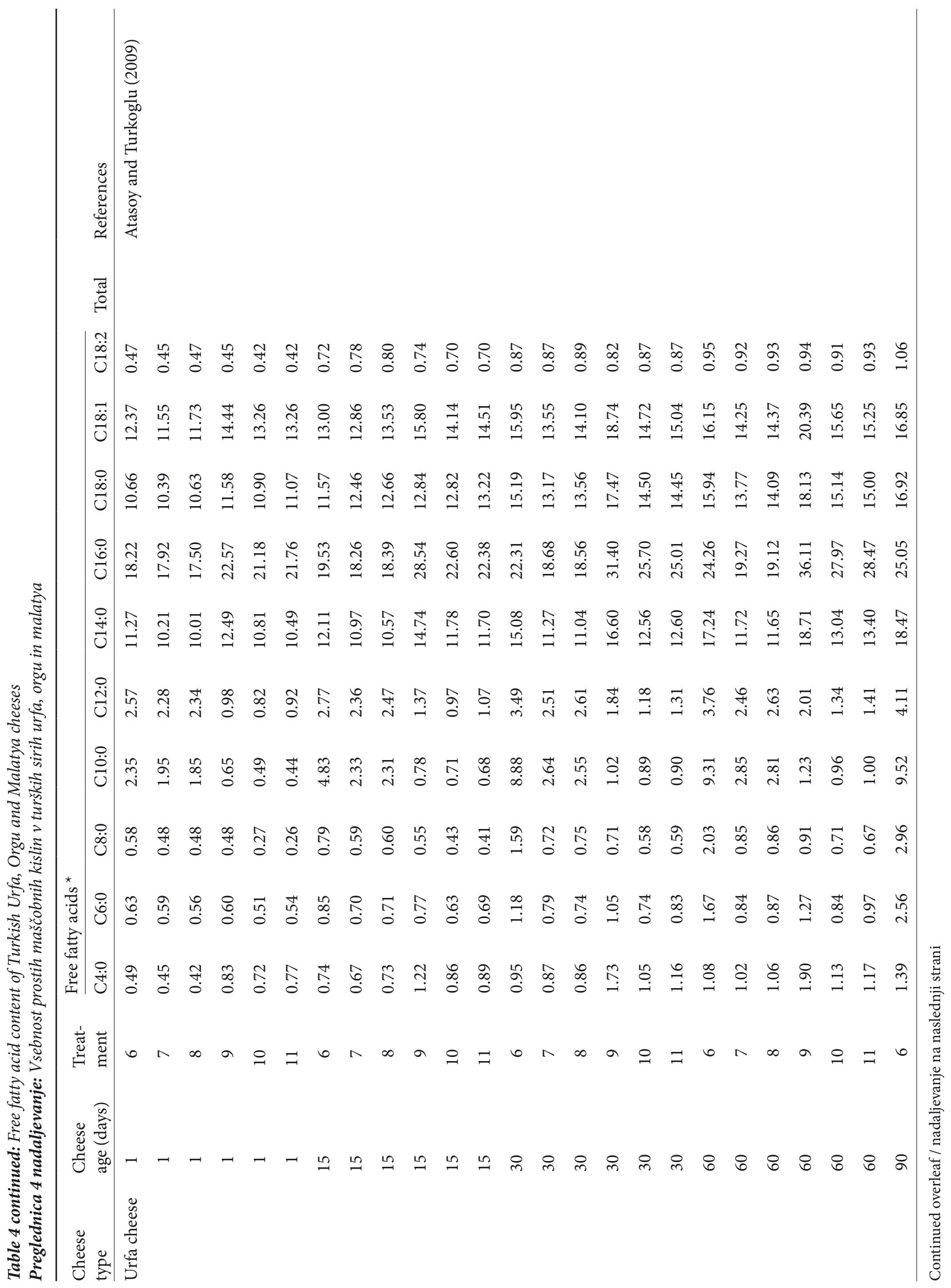




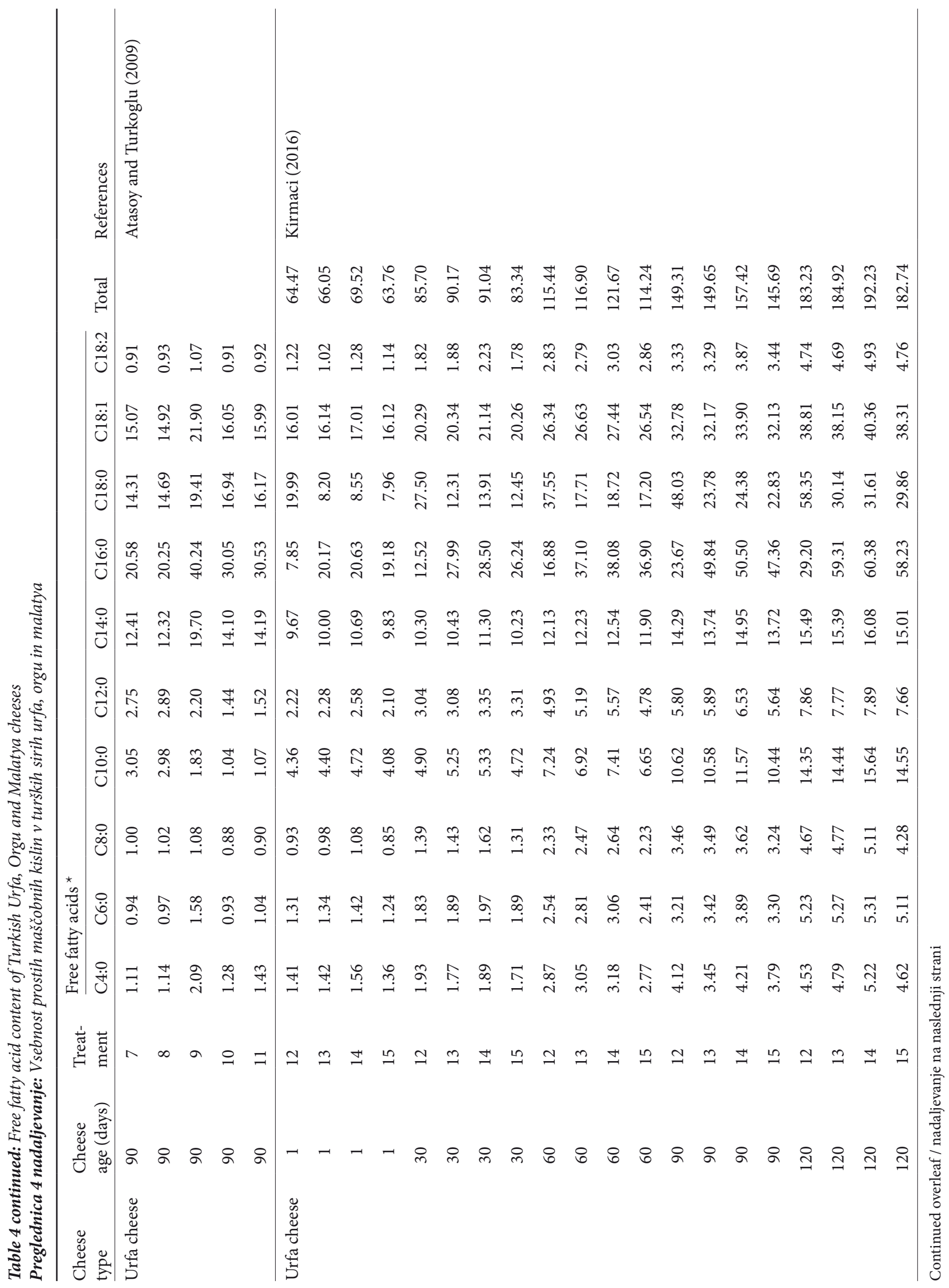




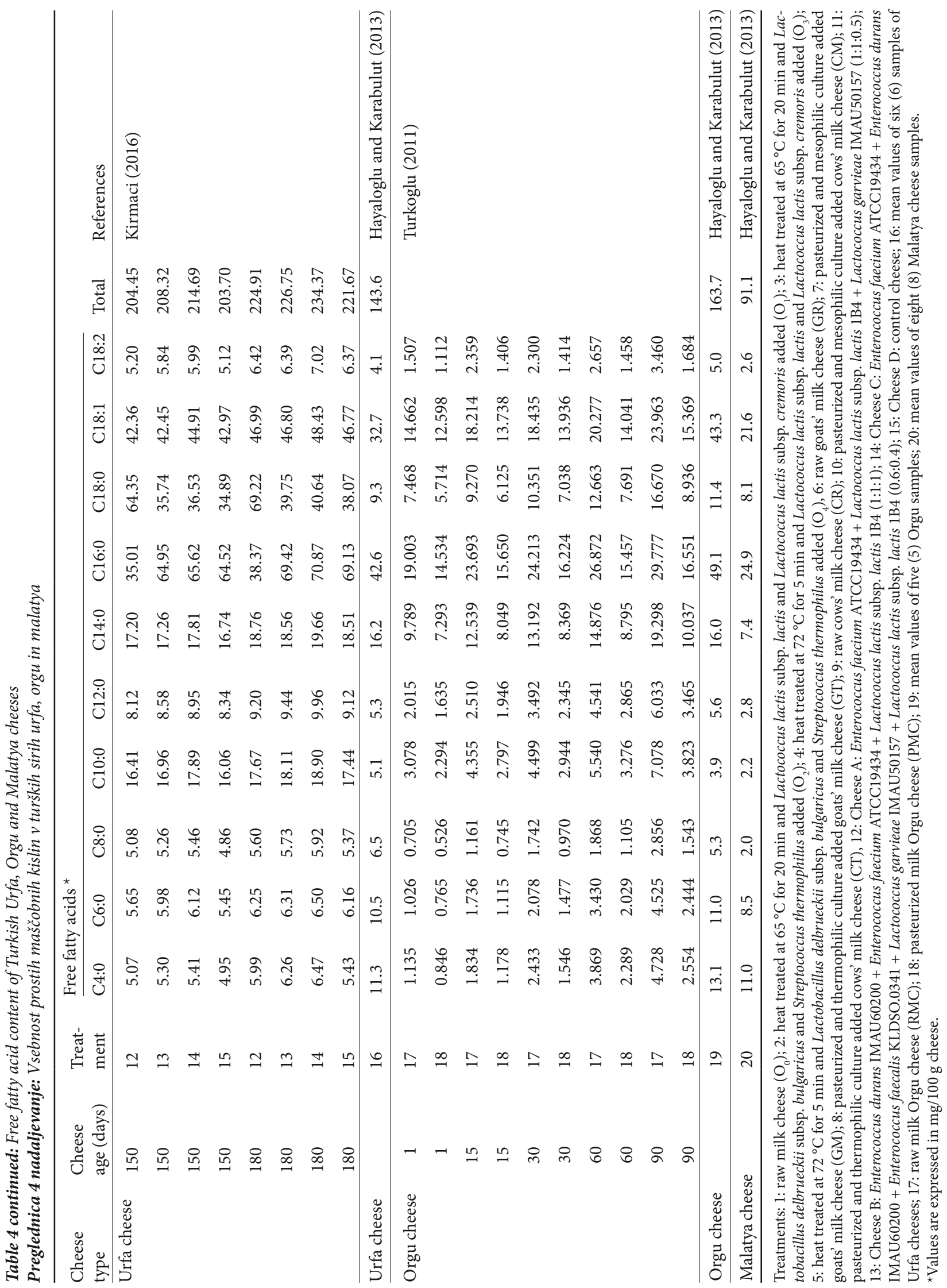


effects of lower heat treatment of milk at $65^{\circ} \mathrm{C}$ on the cheese properties. Also, a very low degree of lipolysis was found in Urfa cheeses.

\subsection{ORGU CHEESE}

Orgu cheese is a traditional cheese that is produced especially in the South-eastern regions of Turkey. It is a semi-hard cheese with high fat level, processed by scalding and kneading of the curd and ripened in brine. Scalded and melted cheese is kneaded to give an Orgu shape (Turkoglu et al., 2003; Celik and Turkoglu, 2007). It is mainly produced from ewe's milk but also goat's and cow's milk are used when ewe's milk is not available or available in insufficient amounts (Turkoglu et al., 2003; Celik and Turkoglu, 2007). Celik and Turkoglu (2007) study the changes in composition and biochemical properties of traditional Orgu cheese made from raw (RMC) or pasteurized (PMC) cow's milk during a ripening period of nineteen (90) days. In case of pasteurized milk cheese starter culture (1\%), $\mathrm{CaCl}_{2}(0.8 \%)$ and rennet $(1: 15.000)$ are added to the milk (Celik and Turkoglu, 2007).

The evaluation of lipolysis expressed as acid degree value (ADV) (mg KOH/g fat) showed that these two experimental Orgu cheeses (raw and pasteurized) undergo little lipolysis. In both cheeses the acid degree value (ADV) increased significantly $(p<0.05)$ along with the ripening time. The ADV was significantly lower in the pasteurized milk Orgu cheese (PMC) than in the raw milk Orgu cheese (RMC) (Table 3 ).

Turkoglu (2011) made two batches of Orgu cheese. One batch was made from raw cow's milk while another batch was made from pasteurized cows' milk. In the case of pasteurized milk cheese Streptococcus thermophilus and Lactobacillus bulgaricus were used as starter cultures. The free fatty acid content of Orgu cheeses during ripening was studied. The results showed that during ripening restricted lipolysis occurred in the pasteurized milk Orgu cheese (PMC) as compared to the raw milk Orgu cheese (RMC) (Table 4). The increase of FFAs in the raw milk cheese (RMC) was significantly higher than that of the pasteurized milk cheese (PMC) due to the activity of lipases from the natural micro flora. The starter culture used and the milk lipases that survived of the pasteurization process were responsible for the lipolysis in pasteurized Orgu cheese. Palmitic, oleic, myristic, stearic and capric acids were the main free fatty acids found in both Orgu cheeses (raw and pasteurized) during ripening (Table 4). These acids represented together the $82 \%$ of total free fatty acids. The pasteurization of milk prior to cheese-making was found to have a significant effect on lipolysis throughout cheese ripening as well as to the relative amounts of short-chain free fatty acids (Table 4). Native lipases and/or non starter lactic acid bacteria were mainly responsible for the development of lipolysis in Orgu cheese. Generally, the total free fatty acids content of Orgu cheese was significantly lower than that of many other cheese varieties.

Hayaloglu and Karabulut (2013) examined the free fatty acids profile of eleven different cheese varieties that are sold in Turkey. Cheese samples were collected from different Turkish regions in 2009 year. Orgu cheese was one of the cheese varieties examined by these authors. Five (5) samples of Orgu cheese were examined. The free fatty acid profile of Orgu cheese is shown in Table 4. Palmitic acid (C16:0) and oleic acid (C18:1) were two of the main free fatty acids found in Orgu cheese. Their amounts were $49.1 \mathrm{mg} / 100 \mathrm{~g}$ cheese for palmitic acid (C16:0) and $43.3 \mathrm{mg} / 100 \mathrm{~g}$ cheese for oleic acid (C18:1) (Table 4).

\subsection{MALATYA CHEESE}

Malatya cheese is a variety of Turkish cheese that is ripened in brine. The manufacture of Malatya cheese resembles to that of Turkish Hellim cheese with minor differences. Malatya cheese is defined as a farmhouse halloumi-type cheese which is traditionally made in farms and villages from raw ewe's or cow's milk or a mixture of them and no starter cultures are added. Thus acidification is brought about by the natural microflora of the milk. In order to standardize the production process of Malatya cheese recently some cheese makers used pasteurized milk and starter cultures. Scalding of the curd at $80-90{ }^{\circ} \mathrm{C}$ in hot water or its own whey is an important step in Malatya cheese making which influences the biochemical and ripening properties of the cheese. Malatya cheese is ripened in brine $(10-12 \% \mathrm{NaCl})$ for at least 60 days at $6-8{ }^{\circ} \mathrm{C}$. Malatya cheese can also be consumed as fresh and unsalted. Fresh Malatya cheese is a semi-hard cheese with no openings or holes, has an elastic and sliceable texture, a milky or creamy taste and a yellowish color (Hayaloglu et al., 2008).

Hayaloglu and Karabulut (2013) studied the free fatty acids profiles of eleven (11) different cheese varieties such as Civil, Divle Tulum, Ezine, Malatya, Mihalic, Orgu cheese etc that are sold in Turkey. Cheeses were collected from different Turkish regions in the year 2009 and the criteria for samples collection were the cheeses to be as old as $2-8$ months or longer. Besides, the fully ripened ones and ready for sale cheeses were selected as far as possible. As some cheeses are still made by artisanal methods without packing or labeling their production 
time was estimated based on the cheese makers declaration. Eight (8) samples of Malatya cheese were examined. The mean free fatty acid profile of these samples is appeared in Table 4. The results of Hayaloglu and Karabulut (2013) showed that Malatya cheese had a low degree of lipolysis.

\subsection{RAS CHEESE}

Ras cheese is the most popular hard cheese in Egypt that is manufactured in small dairies located in the Delta region. This cheese is referred to have similarities to the Greek cheese named 'Kefalotyri' (Phelan et al., 1993). Ras cheese is made from raw cow's milk or a mixture of cow's and buffalo's milks. No starter cultures are used (Awad et al., 2003). New standards have been published by the Egyptian Organization for Standardization and Quality Control and indicate that all cheeses must be produced from pasteurized milk (Awad, 2006). In this case, the use of starter cultures is required. Awad (2006) manufactured Ras cheese from raw or pasteurized milk and studied the flavour changes during its ripening. The milk was divided into two parts. The first part of the milk was used for making raw milk Ras cheese. The second part of the milk was pasteurized at $63{ }^{\circ} \mathrm{C}$ for 30 minutes, cooled to $30{ }^{\circ} \mathrm{C}$ and calcium chloride $(0.02 \%$, w/w) was added. Then, the pasteurized milk was divided into two parts. In the first part (part A) a FRC60 (direct to vat set) thermophilic starter culture (Chr. Hansen, Denmark, 0.01\%, w/w) was added, while in the second part (part B) aYY47 (direct to vat set) thermophilic starter culture (Chr. Hansen, Denmark, 0.01\%, w/w) was added. The level of free fatty acids (FFAs) was significantly increased during Ras cheese ripening. The raw milk Ras cheese had significantly higher levels of free fatty acids during ripening. However, no significant differences in the free fatty acid content between the two pasteurized milk Ras cheeses made by the two different starter cultures were found. Raw milk Ras cheese developed more quickly its characteristic flavor than the pasteurized one. Nevertheless, the flavor of pasteurized cheese was acceptable. Although pasteurized Ras cheese may not develop the typical flavor of raw Ras cheese, it may be preferred by the consumers as being safer.

\subsection{SUDANESE WHITE CHEESE}

Despite the fact that a number of food safety agencies around the world have warned the risk of raw-milk cheeses, the small-scale cheese makers in Sudan use raw milk in cheese making process as it is considered to pro- duce cheese with a more intense flavor than cheeses made from pasteurized or heat-treated milks. This is mainly due to the high levels of native lactic acid bacteria found in the raw milk. Elkhider et al. (2012) described the cheese making process of Sudanese white cheese in a rural area. The milk was sieved with a piece of clean cloth into plastic barrels. The salt (6-10 \%) was dissolved and sieved so as to remove the impurities. Two tablets of rennet $/ 100 \mathrm{~kg}$ milk were dissolved in a little amount of milk, were mixed with the rest of milk and stirred for five minutes using long wooden paddle. Afterwards, the barrel was covered with cheese cloth and left to stand undisturbed for 4-6 hours to allow the milk to coagulate. The coagulated mixture was then transferred into wooden moulds, lined with cotton cloth, placed on wooden benches and left to drain overnight. Suitable weights were put on the mould cover for about 6 hours. Next day the cheese was removed from the moulds and cut into small cubes. The cut cheese was preserved into its own whey, by packing it into retail containers. The containers are left unsoldered till next morning, in order to allow further drainage of whey to take place. Then it was labeled. El Zubier et al. (2014) studied the effect of packaging material on the ripening indices of Sudanese cheese during its storage period. Sudanese white cheese was purchased from El Dueim town and packed into five different packaging materials: metal tin containers (lined with polyethylene bags and non-lined), plastic containers (lined with polyethylene bags and non-lined) and metal gallon. Sudanese white cheese that was stored in metal gallon material was used as a control sample. Each pack weights $2 \mathrm{~kg}$ and the cheese samples were stored for 6 months at $30{ }^{\circ} \mathrm{C} \pm 5{ }^{\circ} \mathrm{C}$ (room temperature). The results of the effect of packaging material and storage time on the volatile fatty acids of Sudanese white cheese are presented in Table 5. The volatile fatty acid content of the cheese samples was significantly $(p<0.05)$ and progressively increased during the storage period. The initial volatile fatty acid value was 6.25 0.1 N ml NaOH/100 g cheese and increased quickly during the first two weeks to $33.50 .1 \mathrm{~N} \mathrm{ml} \mathrm{NaOH} / 100 \mathrm{~g}$ cheese for the samples packed in lined plastic containers (Table 5). Then the volatile fatty acid content increased gradually to the value of $62.50 .1 \mathrm{~N} \mathrm{ml} \mathrm{NaOH} / 100 \mathrm{~g}$ cheese at day 180 in the cheese that was stored in metal ion. The volatile fatty acid content of cheese packed in plastic containers was found to be higher than that of cheeses packed in anti acid cans. This may be attributed to the increased activity of lipolytic agents found in plastic containers. The study of El Zubier et al. (2014) showed that plastic containers are suitable for a short period of cheese storage (45 days) of Sudanese white cheese while tin containers could be used for a longer time of cheese storage (up to 180 days). 


\subsection{CORRIENTES ARTISANAL CHEESE}

Corientes Artisanal Cheese' is an Argentinean cow's milk variety. The province of Corrientes in Northeastern Argentina has a very long tradition of 'Corrientes Artisanal Cheese' making, Although this cheese does not have a Protected Designation of Origin Status, it plays an important role in the dairy farmers' economy, especially for women. The amount of its production is very important although there are no statistics currently available. This cheese is a fatty blocked shape semi-soft product with a slightly acid sour flavor. Its weight is $1.00-1.50 \mathrm{~kg}$ per piece. Raw cow's milk and homemade bovine milk coagulant are used for making this cheese. Its production is based on the continuous fermentation that occurs as a result of the development of the microbiota naturally present in the raw material. Differences in sensory quality between raw cheeses and pasteurized ones are mainly due to the microbial population that is found in the raw milk as well as to the factory environment. Due to the absence of dairy industries, Corrientes region of Argentina is an area where cheese production is artisanal and in a small-scale. So there is a natural ecosystem of wild lactic acid bacteria strains but free from commercial lactic acid bacteria strains. Traditionally, Corrientes Artisanal Cheese is sold as fresh on the first week of its production. However, for economic reasons and when the season of high production declines some cheese makers produce cheeses that are aged for one month. Vasek et al. (2013) evaluate the lipolysis level throughout the manufacture and ripening of Corrientes Artisanal Cheese. Lipolysis was measured as acid degree value (ADV) on day one (1), day fifth (5), day seven (7), day fifteen (15) and day thirty (30) cheese. The acid degree value increased during cheese ripening from $1.03 \pm 0.0 \mathrm{mg} \mathrm{KOH} / \mathrm{g}$ fat in the day 1 old cheese to $3.76 \pm 0.7 \mathrm{mg} \mathrm{KOH} / \mathrm{g}$ fat in the 30 day cheese (Table 3 ).

These values, expressed according to the American
Public Health Association (Case et al., 1985) were $<0.4$, corresponding to normal fat indicating a very limited lipolytic activity of enzymes from the microbiota or the rennet.

\subsection{ANEJO CHEESE}

Anejo cheese is an artisanal semi hard to hard Mexican cheese that is produced in the central state of Estado de Mexico. The south western region of the state Estado de Mexico was explored to delimit the area of Anejo cheese production. It is made from raw milk that is taken from breeds of dual purpose cows. Its production is high during the summer time or the rain season, from August to October, when cows graze natural pasture. However, in a smaller rate of production, a few producers make this cheese during the rest of the year. Anejo cheese has a rectangular shape with a characteristic mounted surface. It could be covered or not with a paste of guajillo chili which gives it an attractive red color. Anejo cheese could be consumed as fresh, 15 days old to one month old or three to twelve months old. Hernandes-Morales et al. (2010) studied the free volatile fatty acid content of Anejo cheese. These authors choose the country of Zacazonapan as a representantive of Anejo cheese production. Cheese samples (A, B, C, D, E and F) were taken from six producers/dairies. Five of them were dairies that produced Anejo cheese throughout the year while one of them was a dairy that produced Anejo cheese only during the summer season. In the month October where it was the peak of Anejo cheese production three blocks of Anejo cheese were taken from each of the six dairies at the day of their manufacture. Nevertheless, all instrumental and sensory analyses of the cheese samples were made 23-27 days after manufacture. Three free volatile fatty acids were detected in Anejo cheese. Acetic acid was the main volatile acid found in the highest concentration.

Table 5: Changes in volatile fatty acids content $(\mathrm{ml} 0.1 \mathrm{~N} \mathrm{NaOH})$ of Sudanese white soft cheese during storage period as affected by type of packaging

Preglednica 5: Spremembe vsebnosti hlapnih maščobnih kislin ( $m l$ 0,1 N NaOH) v sudanskem belem mehkem siru med skladiščenjem kot posledica različne embalaže

\begin{tabular}{|c|c|c|c|c|c|c|c|c|c|c|c|}
\hline \multirow{2}{*}{$\begin{array}{l}\text { Packaging } \\
\text { type }\end{array}$} & \multicolumn{10}{|c|}{ Storage period (days) } & \multirow[b]{2}{*}{ Reference } \\
\hline & 0 & 7 & 15 & 30 & 45 & 60 & 75 & 120 & 150 & 180 & \\
\hline MT & 6.25 & 23.00 & 27.00 & 30.50 & 34.50 & 40.00 & 42.00 & 64.00 & 63.50 & 63.50 & El Zubier et al. (2014) \\
\hline MTL & 6.25 & 24.00 & 27.00 & 34.00 & 35.00 & 39.00 & 45.00 & 65.50 & 61.00 & 61.50 & \\
\hline $\mathrm{P}$ & 6.25 & 28.00 & 32.00 & 54.50 & 53.00 & 56.00 & 64.50 & 64.75 & 50.00 & 62.50 & \\
\hline PL & 6.25 & 28.00 & 33.50 & 62.50 & 62.50 & 65.00 & 65.00 & 64.75 & 58.15 & 62.50 & \\
\hline MG & 6.25 & 28.00 & 29.50 & 48.00 & 45.00 & 45.00 & 56.00 & 64.75 & 58.15 & 62.50 & \\
\hline
\end{tabular}

MT: Metal tin, MTL: Metal tin lined with polyethylene bags, P: Plastic, PL: Plastic lined with polyethylene bags, MG: Metal gallon 
Butyric acid was the second most abundant fatty acid detected (Table 6). However, propionic acid was detected in only four of the cheese samples. The cheese B had the highest values for propionic and butyric acids (Table 6). This was probably due to the lipase activity of the milk and of the commercial rennet. The commercial rennet is known to have a strong lipolytic activity (Sousa et al., 2001). Cheese $C$ showed the highest values of acetic acid (Table 6). This could be associated to the uninhibited chymosin activity from calf rennet having used in its highest concentration for coagulating cheese C.

\section{CONCLUSIONS}

Although there is an extensive knowledge on the lipolysis level of certain cheese varieties, the lipolysis profile of non-European raw milk cheeses is not well known to the wide public. This review has collected literature data on the lipolysis profile of some non-European raw milk cheese varieties and provides a comprehensive overview of their properties and characteristics. Lipolysis in raw milk cheeses is different from that of pasteurized milk cheeses as pasteurization inactivates some enzymes that could play an important role in cheese ripening eg. milk lipases. Cheeses made from raw milk process strong and unique flavours and are still sold in many parts of the world although due to hygienic reasons most cheeses are made nowdays from pasteurized milk.

The lipolysis level of the non-European raw milk cheeses referred in this study varies according to the cheese type, age and manufacture procedure, indicating that lipolysis level may be a useful index for characterizing these cheeses. Intensive lipolysis, which is found by the high levels of FFAs and their acid degree value, is observed in cheeses ripened in an animal skin-bag such as the Turkish Tulum cheese. Lipolysis is the main biochemical process that leads to the formation of free fatty acids in cheeses that ripen in an animal skin and is responsible for the formation of cheese aroma and flavour. The increase of the short chain free fatty acids in the traditional Iranian cheese named 'Poosti', an animal skin ripened cheese, could be a result of the lipoprotein lipase of raw milk as well as of the lipases released from the microbial population of the raw milk and skin. The level of lipolysis in the Turkish Urfa cheese, an artisanal brined type cheese, was low mainly due to its storing in high salt brine (higher than $12 \%$, w/v). However, Urfa cheeses made from raw milk withought starter bacteria showed significantly higher lipolysis than Urfa cheeses made from pasteurized milk and starters added. In the raw milk Lihgvan Iranian cheese lipolysis plays an important role on its flavor formation. The Turkish Malatya cheese, in which high temperature curd scalding is applied, had also a low degree of lipolysis, as this process inhibits the enzymes from milk and microorganisms. The variation in lipolysis index of the Turkish Sepet (basket) cheese samples could be attributed to variation in microbial loads, milk species, ripening conditions and season. Sudanese white cheese, a traditional raw milk cheese of Sudan showed a low degree of lipolysis. In Anejo cheese, an artisanal semi-hard to hard Mexican cheese, acetic acid and butyric acid were the most abundant free fatty acids detected.

\section{REFERENCES}

Aminifar, M., \& Emam-Djomeh, Z. (2014). Changes of texture, microstructure and free fatty acid contents of Lighvan cheese during accelerating ripening with lipase. Journal of Agricultural Science and Technology, 16(1), 113-123. Retrieved from http://jast.modares.ac.ir/article_10304.html

Atasoy, A. F., \& Turkoglu, H. (2008). Changes of composition and free fatty acid contents of Urfa cheeses (a white-brined Turkish cheese) during ripening: Effects of heat treatments and starter cultures. Food Chemistry, 110, 598-604. doi:10.1016/j.foodchem.2008.02.046

Atasoy, A. F., \& Turkoglu, H. (2009). Lipolysis in Urfa cheese

Table 6: Free volatile fatty acid analysis of the Mexican Anejo cheese Preglednica 6: Analiza prostih hlapnih maščobnih kislin v mehiškem siru anejo

\begin{tabular}{lllcl}
\hline & \multicolumn{2}{l}{ Free volatile fatty acids } & & \\
\cline { 2 - 4 } Cheese & Acetic acid (C2:0) & Propionic acid (C3:0) & Butyric acid (C4:0) & Reference \\
\hline A & 1240 & nd & 107 & Hernadez-Morales et al. (2010) \\
B & 2600 & 674 & 1500 & \\
C & 3600 & 369 & 428 & \\
D & 548 & nd & 86 & \\
E & 1220 & 89 & 145 & \\
F & 1230 & 52 & 253 & \\
\hline
\end{tabular}

A, B, C, D, E, F: six cheese producers, nd: not detected. Values are expressed as $\mu \mathrm{g} / \mathrm{g}$ cheese. 
produced from raw and pasteurized goats' and cows; milk with mesophilic or thermophilic cultures during ripening. Food Chemistry, 115, 71-78. doi:10.1016/j.foodchem.2008.11.061

Attaie, R. (2009). Quantification of volatile compounds in goat milk Jack cheese using static headspace gas chromatography. Journal of Dairy Science , 92, 2435-2443. doi:10.3168/ jds.2008-1732

Awad, S., El-Attar, A., Ayad, A. H., \& El-Soda, M. (2003). Characterization of Egyptian Ras cheese. 1. Sensory evaluation, rheological, physic-chemical properties and microbiological analysis. Egyptian Journal of Dairy Science, 31, 289-303.

Awad, S. (2006). Texture and flavor development in Ras cheese made from raw and pasteurized milk. Food Chemistry, 97, 394-400. doi:10.1016/j.foodchem.2005.05.012

Casalta, E., Sorba, J. M., Aigle, M., \& Ogier, J. C. (2009). Diversity and dynamics of the microbial community during the manufacture of Calenzana, an artisanal Corsican cheese. International Journal of Food Microbiology, 133, 243-251. doi:10.1016/j.ijfoodmicro.2009.05.022

Case, R. A., Bradley Junior, R. L., \& Williams, R. R. (1985). Chemical and physical methods. In G. H. Richardson (Ed.), Standard methods for the examination of dairy products (pp. 324-404). Washington: American Public Health Association.

Celik, S., \& Turkoglu, H. (2007). Ripening of traditional Orgu cheese manufactured with raw or pasteurized milk: Composition and biochemical properties. International Journal of Dairy Technology, 60, 253-258. doi:10.1111/j.14710307.2007.00344.x

Ceylan, Z. G., Caglar, A., \& Cakmakci, S. (2007). Some physicochemical, microbiological and sensory properties of Tulum cheese produced from ewe's milk via modified method. International Journal of Dairy Technology, 60, 191-196. doi:10.1111/j.1471-0307.2007.00326.x

Chiofalo, A. Z., Costa, R., Liotta, L., Mondello, L., Dugo, P., \& Chiofalo, V. (2004). Characterization of Maltese goat milk cheese flavor using SPME-GC/MS. South African Journal of Animal Science, 34(Supplement 1), 176-180. Retrieved from http://www.sasas.co.za/sites/sasas.co.za/files/chiofalogoat04_1.pdf

Driessen, F. M. (1989). Heat inactivation of lipases and proteinases (indigenous and bacterial). In Heat induced changes in milk. Bulletion (Vol. 238, pp.71-93). Brussels: International Dairy Federation.

Elkhider, I. A. E., El Zubier, I. E. M., \& Basheir, A. A. (2012). The impact of processing methods on the quality of Sudanese white cheese produced by small scale in New Halfa area. Acta agriculturae Slovenica, 100(2), 131-137. Retrieved from http://aas.bf.uni-lj.si/zootehnika/100-2012/ PDF/100-2012-2-131-137.pdf

El Zubeir, I. E. M., Abdalla, M. I., Ahmed, A. R., \& Mohamed, B. E. (2014). Effect of storage period and packaging type on ripening indices of Sudanese white cheese. Fronties in Food Science and Technology, 1, 1-6. Retrieved from http://www. vkingpub.com

Erkan, D., Korel, F., Karagul Yuceer, Y., \& Kinik, O. (2011). Physicochemical, textural, volatile and sensory profiles of traditional Sepet cheese. Journal of Dairy Science, 94, 43004312. doi:10.3168/jds.2010-3941

Fox, P. F., Guinee, T. P., Cogan, T. M., \& McSweeney, P. L. H. (2000). Fundamentals of cheese science. Gaithersburg, Maryland: Walters Kluwer Company.

Franco, I., Prieto, B., Urdiales, R., Frensco, J. M., \& Carballo, J. (2001). Study of the biochemical changes during ripening of Ahumado de Aliva cheese: a Spanish traditional variety. Food Chemistry, 74, 463-469. doi:10.1016/S03088146(01)00164-9

Frank, D. C., Owen, C. M., \& Patterson, J. (2004). Solid phase microextraction (SPME) combined with gas-chromatography and oflactometry-mass spectrometry for characterization of cheese aroma compounds. LebensmittelWissenschaft \& Technologie, 37, 139-154. doi:10.1016/ S0023-6438(03)00144-0

Guler, Z., \& Uraz, T. (2003). Proteolytic and lipolytic composition of Tulum cheese. Milchwissenschaft, 58, 502-505.

Hayaloglu, A. A., Fox, P. F., Guven, M., \& Cakmakci, S. (2007). Cheeses of Turkey: 1. Varieties ripened in goat-skin bags. Lait, 87, 79-95. doi:10.1051/lait:2007006

Hayaloglu, A. A., Ozer, B. H., \& Fox, P. F . (2008). Cheeses of Turkey: 2. Varieties ripened under brine. Dairy Science \& Technology, 88, 225-244. doi:10.1051/dst:2007014

Hayaloglu, A. A., \& Karabulut, I. (2013). Characterization and comparison of free fatty acids profiles of eleven varieties of Turkish cheeses. International Journal of Food Properties, 16, 1407-1416. doi:10.1080/10942912.2011.587626

Hemmatian, M., Aminifar, M., \& Attar, A. (2015). Investigation on the protein degradation, free fatty acid content and area fraction of Poosti cheese, Iranian traditional cheese ripened in skin. Nutrition and Food Sciences Research, 2, 55-62.

Hernandez-Morales, C., Hernandez-Montes, A., Aguirre-Mandujano, E., \& Villeras de Gante, A. (2010). Physicochemical, microbiological, textural and sensory characterization of Mexican Anejo cheese. International Journal of Dairy Technology, 63, 552-560. doi:10.1111/j.1471-0307.2010.00615.x

Kafili, T., Ravazi, S. H., Emam Djomeh, Z., Naghavi, M. R., Alvarez-Martin, P., \& Mayo, B. (2009). Microbial characterization of Iranian traditional Lighvan cheese over manufacturing and ripening via culturing and PCR-DGGE Analysis: Identification and typing of Dominant Lactobacilli. European Food Research and Technology, 229, 83-92. doi:10.1007/s00217-009-1028-x

Kalit, M. T., Kalit, S., \& Havranek, J. (2010). An overview of researches on cheeses ripening in animal skin. Mljekarstvo, 60, 149-155. Retrieved from: http://hrcak.srce.hr/ file/89041

Kalit, M. T., Kalit, S., Delas, I., Kelava, N., Karolyi, D., Kaic, D., ... Havranek, J. (2014). Changes in the composition and sensory properties of Croatian cheese in a lamb skin sack (sir iz misine) during ripening. International Journal of Dairy Technology, 67, 255-264. doi:10.1111/14710307.12117

Kamber, U. (2008). The traditional cheeses of Turkey: The Aegean region. Food Reviews International, 24, 39-61. doi:10.1080/87559120701762195

Kara, R. (2012). Traditional A Cheese: Afyon Tulum Cheese. Kocatepe Veterinary Journal, 5, 45-48. 
Kara, R., Bulut, S., \& Akkaya, L. (2014). Determination of fatty acid composition of Afyon Tulum cheese. Journal of Food and Nutrition Research, 2, 17-20. doi:10.1269/jfnr-2-1-3

Katsiari, M. C., Voutsinas, L. P., Alichanidis, E., \& Roussis, I. G. (2000). Lipolysis in reduced sodium Feta cheese made by partial substitution of $\mathrm{NaCl}$ by $\mathrm{KCl}$. International Dairy Journal, 10, 369-373. doi:10.1016/S0958-6946(00)00067-4

Kinik, O., Ergullu, E., Akbulut, N. (1999). A study on the production and some characteristics of Sepet cheese. Giba, 24, $151-161$

Kirmaci, A. H. (2016). Effect of wild strains used as starter cultures on free fatty acid profile of Urfa cheese. Polish Journal of Food and Nutrition Sciences, 66, 303-310. doi:10.1515/ pjfns-2015-0034

Kurt, A. (1996). Milk technology. Publication No: 257. Erzurum, Turkey: Ataturk University Press.

Lavasani, A. R. S., Ehsani, M. R., Mirdamadi, S., \& Mousavi, M. A. E. Z. (2012). Changes in physicochemical and organoleptic properties of traditional Iranian cheese Lighvan during ripening. International Journal of Dairy Technology, 65, 64-70. doi:10.1111/j.1471-0307.2011.00724.x

Masoud, W., Vogensen, F. K., Lillevang, S., Abu Al-Soud, W., Sørensen, S. J., \& Jakobsen, M. (2012). The fate of indigenous microbiota, starter cultures, Escherichia coli, Listeria innocua and Staphylococcus aureus in Danish raw milk and cheeses determined by pyrosequencing and quantitative real time (qRT)-PCR. International Journal of Food Microbiology, 153, 192-202. doi:10.1016/j.ijfoodmicro.2011.11.014

Mirzaei, H., Ghiasi Khosroshahi, A., Karim, G. (2008). The microbiological and chemical quality of traditional Lighvan cheese (white cheese in brine) produced in Tabriz. Journal of Animal and Veterinary Advances, 7, 1594-1599. Retrieved from http://medwelljournals.com/abstract/?doi= javaa.2008.1594.1599

Mirzaei, H. (2011). Microbiological changes in Lighvan cheese throughout its manufacture and ripening. African Journal of Microbiology Research, 5(13), 1609-1614. doi:10.5897/ AJMR11.111

Nelson, J. H. (1984). Should cheese be refrigerated? Dairy Food Sanitation, 3(10), 372-375.

Nogueira, M. C. L., Lubachevsky, G., \& Rankin, S. A. (2005). A study of the volatile composition of Minas cheese. LWTFood Science and Technology, 38, 555-563. doi:10.1016/j. lwt.2004.07.019

Ozer, B., Atasoy, F., \& Akin, S. (2002). Some properties of urfa cheese (a traditional white-brined Turkish cheese) produced from bovine and ovine milks. International Journal Dairy Technology, 55, 94-99. doi:10.1046/j.14710307.2002.00040.x

Pandey, P. K., Ramaswamy, H. S., \& St-Gelais, D. (2003). Evolution of $\mathrm{pH}$ change kinetics during various stages of Cheddar cheese-making from raw, pasteurized, micro-filtered and high-pressure-treated milk. Lebensmittel-Wissenchaftand-Technologie, 36(5), 497-506. doi:10.1016/S00236438(03)00045-8

Pavia, M., Trujillo, A. J., Sendra, E., Guamis, B., Ferragut, V. (2000). Free fatty acid content of Manchego-type cheese salted by brine vacuum impregnation. International Dairy Journal, 10, 563-568. doi:10.1016/S0958-6946(00)00083-2

Phelan, J. A., Renaud, L., \& Fox, P.F . (1993). Some non European cheese varieties. In P. F. Fox (Ed.), Cheese, chemistry, physics and microbiology (pp. 421-465). London: Chapman and Hall. doi:10.1007/978-1-4615-2648-3_14

Salameh, C., Banon, S., Hosri, \& C., Scher, J. (2016). An overview of recent studies on the main traditional fermented milks and white cheeses in the Mediterranean region. Food Reviews International, 32, 256-279. doi:10.1080/87559129. 2015.1075210

Serhan, M., Linder, M., Hosri, C., \& Fanni, J. (2010). Changes in proteolysis and volatile fraction during ripening of Darfiyeh, a Lebanese artisanal raw goat's milk cheese. Small Ruminant Research, 90, 75-82. doi:10.1016/j.smallrumres.2010.01.008

Tavaria, F. K., Reis, P. J. M., Malcata, F. X. (2006). Effect of dairy farm and milk refrigeration on microbiological and microstructural characteristics of matured Serra da Estrela cheese. International Dairy Journal, 16, 895-902. doi:10.1016/j.idairyj.2005.08.010

Turkoglu, H., Ceylan, Z. G., Dayisoglu, K. S. (2003). The microbiological and chemical quality of Orgu cheese produced in Turkey. Pakistan Journal of Nutrition, 2, 92-94. doi:10.3923/ pjn.2003.92.94

Turkoglu, H. (2011). Free fatty acid composition and sensory characteristics of Orgu cheese. Scientific Research and Essays, 6, 1555-1560. doi:10.5897/SRE10.712

Vasek, O. M., Mazza, S. M., \& Giori, G. S. (2013). Physicochemical and microbiological evaluation of corrientes artisanal cheese during ripening. Food Science and Technology, Campinas, 33, 151-160. doi:10.1590/S010120612013005000021

Weichselbaum, E., Benelam, B., \& Costa, H. S. (2009). Synthesis report No. 6: Traditional foods in Europe. European Food Information Resource (EuroFIR). Project Management Office, Institute of Food Research, Norwich, U.K.

West, H. G. (2008). Food fears and raw-milk cheese. Appetite, 51, 25-29. doi:10.1016/j.appet.2008.02.004

Yilmaz, G., Ahmet, A., \& Akin, N. (2005). The effect of microbial lipase on the lipolysis during the ripening of $\mathrm{Tu}$ lum cheese. Journal of Food Engineering, 69, 269-274. doi:10.1016/j.jfoodeng.2004.08.017

Yoon, Y., Lee, S., \& Choi, K-H. (2016). Review. Microbial benefits and risks of raw milk cheese. Food Control, 63, 201-215. doi:10.1016/j.foodcont.2015.11.013 